\title{
ANALISIS DAMPAK TAX MORALE TERHADAP KEPATUHAN PAJAK UMKM: STUDI KASUS KOTA SEMARANG
}

\author{
Muslimah Mahmudah $^{1}$, Deden Dinar Iskandar ${ }^{2}$ \\ Fakultas Ekonomika dan Bisnis Universitas Diponegoro, Jalan Tretes Raya No. 21 Perumnas 2, \\ Kabupaten Tangerang, 15810 \\ Muslimahmahmudah17@gmail.com
}

\begin{abstract}
This study aims to analyze the impact of tax morale on Micro, Small, and Medium Enterprises (MSMEs) tax complianceSemarang City as the case study. This study uses primary data generated from 117 samples of MSMEs in Semarang. Data analysis is performed using binary logistic regression analysis. The results showed that environmental, institutional, ethical, business, and business size variables significantly influence MSMEs tax compliance. On the other hand, variables whose effect on tax compliance is not statistically significant include happiness, religiosity, gender, age, education, and marital status.
\end{abstract}

Keywords : tax morale, tax compliance, MSMEs, binary logistics regression

JEL Classification: E17, H25 


\section{PENDAHULUAN}

Keberhasilan Pemerintah dalam menghimpun penerimaan pajak ditunjukkan oleh banyaknya pendaftaran Nomor Pokok Wajib Pajak (NPWP) dan pelaporan Surat Pemberitahuan Tahunan (SPT).Dalam kasus Jawa Tengah, Jumlah WP terdaftar SPT PPh di Kanwil DJP Jawa Tengah I terus meningkat dari tahun 2013-2015 dengan rata-rata pertumbuhan yakni sebesar 11,92\% dan ratarata pertumbuhan SPT Tahunan PPh yakni sebesar 20,48\%. Namun, rasio kepatuhan pajak tergolong cukup rendah. Hal ini ditunjukkan oleh jumlah Wajib Pajak (WP) yang tercatat pada tahun 2013 hanya sebesar 1.085.0487 dari 1,7 juta masyarakat yang tergolong wajib pajak. Bahkan, sebanyak 394.752 WP tidak menyampaikan kewajibannya untuk membayar Pajak. Jumlah ini sangat kecil apabila dibandingkan dengan $12 \%$ dari total wajib pajak potensial (DJP Kanwil Jateng I, 2017).

Kota Semarang memiliki kontribusi pajak daerah terhadap PAD tertinggi di banding Kotakota Provinsi Jawa Tengah lainnya yakni sebesar 67,93\% (Kemenkeu, 2017). Penerimaan pajak terbesar per klasifikasi lapangan usaha di Kota Semarang ialah sektor perdagangan, hotel, dan restoran sebesar Rp2.951.066,42 juta (DJP Kanwil Jateng I, 2017). Sektor ini menjadi sektor potensial penerimaan pajak karena merupakan sektor yang paling bayak digeluti oleh UMKM. Namun, rasio pencapaian kepatuhan pajak di Kota Semarang tahun 2013-2015secara berturut-turut belum mencapai target 100 persen yakni 75,99\%, 77,38\%, dan 91,13\% (DJP Kanwil Jateng I, 2017).

Jumlah pelaku Usaha Mikro Kecil dan Menengah (UMKM) di Kota Semarang terus mengalami pertumbuhan setiap tahun dengan rata-rata sekitar 1,97\% yang didominasi oleh usaha perdagangan dan industri. Jumlah UMKM Kota Semarang sebanyak 11.692 unit mampu menyerap tenaga kerja sebanyak kurang lebih 18.000 orang. Namun disisi lain, tingkat pertumbuhan usaha yang ada di Kota Semarang memiliki tingkat kepatuhan membayar pajak yang rendah (Seputar Indonesia,2016).

Pemerintah telah menerbitkan PP Nomor 46 tahun 2013 tentang penghasilan yang diterima atau diperoleh oleh Wajib Pajak dengan batasan peredaran bruto dibawah 4,8 miliar dikenakan tarif pajak sebesar $1 \%$ dari omset guna mendorong kepatuhan pajak secara sukarela dan meningkatkan kontribusi penerimaan negara dari UMKM. UMKM wajib dikukuhkan sebagai Pengusaha Kena Pajak (PKP) atau menjadi wajib Pajak Pertambahan Nilai (PPN) apabila memiliki omset melebihi 4,8 miliar sampai dengan suatu bulan dalam tahun buku sebagaimana tercantum dalam Peraturan Menteri Keuangan (PMK) No.197/PMK.03/2013.

Sejak awal diterapkannya sistem perpajakan di dunia, pertanyaan utama yang selalu dicari jawabannya adalah faktor apa yang sebenarnya menyebabkan orang membayar pajak atau tidak membayar pajak sesuai dengan ketentuan. Terdapat dua teori mengenai hal ini, yakni teori ekonomi dan non-ekonomi. Teori ekonomi berargumen bahwa Wajib Pajak di dalam memenuhi kewajiban perpajakannya mendasarkan pada perhitungan ekonomi, yakni seberapa besar manfaat yang diperoleh oleh Wajib Pajak apabila Wajib Pajak melaksanakan peraturan perpajakan atau memutuskan untuk tidak mematuhi peraturan perpajakan. Sedangkan salah satu teori non ekonomi yang bisa menjelaskan adalah teori tax morale (Susila, 2016).

Tax morale menunjukkan motivasi intrinsik untuk mematuhi dan membayar pajak sehingga berkontribusi secara sukarela pada penyediaan barang-barang publik. Apabila wajib pajak memiliki tax morale yang baik, maka tingkat kepatuhan akan tinggi dan pada akhirnya penerimaan pajak akan lebih optimal dan dapat menciptakan kepatuhan sukarela (voluntarily compliance). Faktor-faktor 
penentu non ekonomi ini memiliki dampak kuat terhadap penggelapan pajak. Konsep tax morale membantu menyelesaikan teka-teki kepatuhan pajak, yaitu menjelaskan tingkat kepatuhan pajak yang tinggi di banyak negara dengan tingkat pencegahan yang sangat rendah. (Torgler dan Friedrich, 2007).

Berdasarkan uraian di atas, diperlukan studi tentang dampak berbagai kasus pajak terhadap moral pajak (tax morale) dan kepatuhan pajak (tax compliance). Dalam penelitian ini digunakan UMKM sebagai objek penelitian untuk memahami tax morale dari wajib pajak yakni pengusaha mikro, kecil, dan menengah. Ketika UMKM tersebut memiliki penghasilan di atas Penghasilan Tidak Kena Pajak (PTKP), maka mereka wajib terdaftar sebagai wajib pajak. Dengan begitu mereka harus membayar pajak dan melaporkan Surat Pemberitahuan Tahunan (SPT). Untuk itu, perlu dilakukan suatu penelitian untuk menganalisis hubungan antara tax morale dan kepatuhan pajak UMKM di Kota Semarang.

Penelitian ini memiliki perbedaan dengan penelitian terdahulu yakni kepatuhan pajak sebagai variabel dependen dilihat sebagai kepatuhan materiil bukan sebagai kepatuhan formal. Hal ini guna melihat apakah wajib pajak tersebut membayar pajak secara konsisten atau tidak bukan hanya wajib pajak yang tercatat sehingga penelitian ini menggunakan data primer. Selanjutnya, variabel $\operatorname{tax}$ morale sebagai variabel independen dijabarkan menjadi variabel kebahagiaan, religiusitas, lingkungan, persepsi kelembagaan, dan etika yang diteliti dan dianalisis secara bersamaan untuk melihat dampaknya terhadap kepatuhan pajak. Riset ini menggabungkan variabel-variabel tersebut kedalam model dan desain yang lebih lengkap untuk mendapatkan gambaran yang lebih luas dan menyeluruh. Kemudian, penelitian yang menggunakan variabel tax morale sebagai variabel bebas masih sangat jarang dan sedikit di Indonesia. Selain itu, kebanyakan dari penelitian sejenis menggunakan variabel ekonomi dan demografi sebagai variabel independennya. Jika penelitian sebelumnya menggunakan obyek penelitian yakni wajib pajak pribadi, penelitian ini menggunakan obyek penelitian yakni UMKM.

\section{TINJAUAN PUSTAKA}

\section{Kepatuhan Pajak}

Nurmantu (2005) menjelaskan bahwa kepatuhan pajak adalah suatu keadaan di mana wajib pajak memenuhi dan melaksanakan semua kewajiban dan hak perpajakannya. Beban yang ditanggung oleh Wajib Pajak untuk melaksanakan hak-hak dan kewajiban-kewajiban perpajakannya dikenal dengan konsep yang disebut cost of taxation. Terdapat dua macam kepatuhan yakni kepatuhan formal dan kepatuhan materiil. Kepatuhan formal adalah suatu keadaan di mana WP memenuhi kewajiban perpajakan secara formal sesuai dengan ketentuan formal dalam undangundang perpajakan. Kepatuhan materiil adalah suatu keadaan di mana WP secara substantif memenuhi semua ketentuan materiil perpajakan yakni sesuai isi dan jiwa undang-undang perpajakan. Suatu sistem pemungutan pajak harus memperhitungkan besarnya tax revenue dan biaya pemungutan agar berhasil memenuhi asas revenue productivity. Vogel (dikutip oleh Togler 2003a) menjelaskan terdapat empat jenis pembayar pajak, yakni:

1. Social Taxpayer, yakni seseorang dalam memenuhi kewajiban perpajakannya dipengaruhi oleh norma sosial, perasaan bersalah dan malu serta bereaksi secara sensitif terhadap kepercayaan oranglain.

2. Intrinsic Taxpayer, yakni seseorang yang merasa memiliki kewajiban untuk mematuhi aturan tanpa dipaksa dari luar dan peka terhadap fakta kelembagaan. 
3. Honest taxpayer, yakni seseorang tidak mencari cara untuk menipu pajak sementara yang lain bertindak sebaliknya.

4. Tax evader, yakni seseorang bereaksi terhadap perubahan harga relatif karena hukuman atau probabilitas audit yang lebih tinggi sehingga mereka bertindak sejalan dengan teori pilihan rasional ekonomi standar dengan membandingkan nilai yang diharapkan antara menghindari pajak ataujujur.

\section{Tax Morale}

Tax morale adalah motivasi dasar non ekonomi serta faktor-faktor bekerja dalam mekanisme kepatuhan membayar pajak melalui seperangkat motivasi dasar. Motivasi dasar tersebut adalah (1) motivasi intrinsik, yaitu kepuasan pribadi seperti rasa bangga apabila menjadi wajib pajak patuh atau sebaliknya rasa malu dan merasa bersalah apabila tidak patuh, (2) hubungan timbal balik antara warga negara dan pemerintahan, seperti kerelaan membayar pajak dengan ketersediaan layanan publik, (3) pengaruh teman dan masyarakat, yaitu bagaimana pandangan pihak lain (lingkungan sosial) memengaruhi perilaku membayar pajak, (4) faktor budaya jangka panjang, yaitu nilai-nilai yang sudah tertanam di suatu lingkungan secara lintas generasi, dan (5) informasi yang kurang sempurna, misalnya mengenai probabilitas audit (Luttmer dan Singhal, 2014).

Torgler dan Schaltegger (2005) menjelaskan Tax morale membantu menjelaskan tingkat kepatuhan pajak yang tinggi. Tax morale mengukur perilaku individu dan tax evasion mengukur sikap individu. Sistem pajak yang berkelanjutan didasarkan pada sistem pajak yang adil dan pemerintah yang responsif. Hal ini dicapai jika ada hubungan yang kuat antara wajib pajak dan pemerintah. Selain itu, pandangan kepatuhan pajak seringkali didasarkan pada pandangan tentang masalah penegakan hukum. Namun, penggelapan pajak bukan hanya aktivitas ilegal tapi juga erat kaitannya dengan keputusan kebijakan fiskal (fiscal policy) oleh pemerintah, perilaku petugas pajak, dan aspek budaya. Dampak dari sistem pajak, pengeluaran pajak, efektivitas administrasi, perilaku aparat terhadap pembayar pajak dan besarnya beban pajak (dirasakan) harus dipertimbangkan untuk mendapatkan gambaran yang lebih komprehensif mengenai pertanyaan mengapa orang membayar pajak. Sehingga, tidak hanya tingkat kepatuhan pajak yang diperhatikan akan tetapi tingkat tax morale juga sangat penting untuk memahami perilaku masyarakat dalam membayar pajak. Musgrave (1959) menjelaskan tiga syarat kebijakan fiskal, yakni: alokasi, distribusi, dan stabilisasi. James et al (2001) menjelaskan terdapat dua aspek dalam konteks tax morale. Selain itu, ia menjelaskan bagaimana strategi tax morale atau tax compliance yang optimal. Pertama, pemerintah harus dapat mengalokasikan pajak secara efisien sehingga akan mempengaruhi tingginya tax morale. Kepatuhan pajak dihitung berdasarkan pada analisis biaya individu terhadap keuntungan dan kerugian akan uang yang diharapkan dari kepatuhan dan ketidakpatuhan. Kedua, aspek distribusi mempengaruhi keadilan dan pertimbangan kejadian yang akan mempengaruhi tinggi atau rendahnya tax morale.

\section{Kebahagiaan Pajak (Tax Happiness)}

Kepuasan seseorang terhadap kehidupannya dapat mencerminkan tingkat kesejahteraan individu. Menurut pendapat aliran filsafat Aristotlean (Lubian dan Luca, 2011) berpendapat bahwa terdapat hubungan antara moralitas dan kebahagiaan seseorang. Moralitas dipandang sebagai ilmu untuk mencapai tujuan hidup yakni kebahagiaan. Peran penelitiaan kebahagiaan yakni sebagai upaya untuk memperbaiki sifat dari proses politik. Individu harus memiliki kesempatan untuk hidup yang lebih baik baik secara individu maupun kolektif. Individu harus sadar akan masalah yang berbeda sehingga memerlukan ukuran dan indikator kesejahteraan berbeda yang mencerminkan kesejahteraan. (Frey dan Alois, 2010).Lubian dan Luca (2011) menjelaskan bahwa moral pajak 
berpengaruh positif dan signifikan kuat terhadap kebahagiaan. Terdapat tiga hal yang melatarbelakangi semangat wajib pajak membayar pajak meninggikan tingkat kebahagiaan dalam hidupnya. Pertama, Eudaimonistic Tradition yakni hubungan kebahagiaan dan kemanusiaan dari perilaku keluhuran budi pekerti. Keluhuran budi pekerti ini dijelaskan melalui moral 'keper-pajakan' seseorang membuat syarat-syarat kebahagiaan terpenuhi dalam dirinya. Kedua, Hedonistic Paradox yakni kondisi yang berkebalikan dari perilaku hedonis yang menganggap kesenangan dan kenikmatan materi adalah tujuan utama dalam hidup. Ketiga, Sense of Moral Obligation yakni sifat alamiah manusia sebagai makhluk sosial yang ingin berkhidmat kepada kebaikan. Ketika mereka memberi, maka sejatinya mereka mendapatkan kenikmatan tersendiri karena adanya kewajiban moral di dalam diri setiap insan (nature of human being).

\section{Religiusitas (Religiosity)}

Torgler (2003b) menjelaskan religiusitas meningkatkan moral pajak. Smith (2015) dalam teorinya moral sentimen menjelaskan religiusitas dari sudut pandang rasional dan mencatat bahwa religiusitas bertindak sebagai moral internal. Teori moral atau teori etika normatif dimaksudkan untuk mengetahui tindakan benar dan salah. Moralitas adalah motivasi internal untuk berperilaku baik sesuai dengan perasaan seseorang tentang apa yang sesuai dan tepat dilakukan di situasi tertentu terlepas dari legalitas tindakannya. Tittle (1980) menjelaskan seseorang akan lebih rela untuk mematuhi hukum ketika mereka percaya bahwa hukum tersebut sesuai dengan nilai moral mereka. Agama menyajikan dasar penting untuk integrasi sosial dan menghindari bentuk perilaku yang menyimpang seperti penghindaran pajak.

\section{Lingkungan}

Allingham dan Sandmo (1972) menjelaskan penghindaran pajak dapat dipengaruhi oleh norma sosial jika individu takut kehilangan reputasinya atau mengalami stigmatisasi saat berperilaku tidak jujur. Wajib pajak cenderung akan patuh terhadap pajak jika terkena sanksi sosial. Menurut (Cialdini dan Melanie, 1998), Norma sosial adalah peraturan dan standar yang dipahami oleh anggota kelompok sebagai panduan dan batasan perilaku sosial tanpa adanya paksaan hukum.Menurut Lewis (dikutip oleh Torgler, 2003a) menjelaskan bahwa rasa bersalah muncul saat individu menyadari hal yang dilakukan tidak bertanggungjawab dan melanggar peraturan dan norma sosial. Jika orang percaya bahwa orang lain jujur, kesediaan mereka untuk membayar pajak meningkat. Jika individu melihat orang lain menghindari pajak, motivasi intrinsik mereka untuk mematuhi pajak menurun. Norma sosial dari kepatuhan pajak dapat dipengaruhi oleh komunikasi kelompok.Bohnet dan Frey (1994) berpendapat komunikasi mengubah keputusan kelompok menjadi keputusan pribadi. Informasi yang dihasilkan dari diskusi kelompok membantu individu untuk memperjelas urutan dan peringkat preferensi mereka. Bobek et.al. (2012) menjelaskan bahwa secara umum norma sosial berpengaruh terhadap perilaku kepatuhan pajak.

\section{Persepsi Kelembagaan}

Torgler (2003a) menjelaskan pentingnya kelembagaan dalam meningkatkan moral pajak. Sistem pajak yang tidak adil dapat meningkatkan insentif untuk merasionalkan kecurangan.Wajib pajak cenderung lebih mematuhi undang-undang jika pajak yang dibayarkan sesuai dengan layanan yang diberikan. Kepercayaan terhadap pemerintah, administrasi pajak, dan sistem hukum cenderung meningkatkan moral pajak sehingga pembayar pajak bersedia untuk berkontribusi untuk membayar pajak. Tingginya beban pajak dan tingginya tingkat korupsi menjadi faktor utama seseorang menghindari pajak. Kemudian, rendahnya tingkat audit dan denda juga dapat menimbulkan keraguan tentang kekuatan otoritas pajak dan menyebabkan ketidakpercayaan dalam efektivitas dan kredibilitas kerja otoritas pajak tersebut. Kelembagaan dapat dimodifikasi untuk menghasilkan hasil 
fiskal yang lebih baik dan tingkat shadow economy yang lebih rendah. Jika masyarakat merasa bahwa kepentingan (preferensi) benar-benar terwakili oleh institusi politik, maka shadow economy akan menurun dan kepatuhan pajak meningkat. Selain itu, Torgler (2003a) menemukan bahwa orang yang berpendidikan semakin tinggi dan wirausaha memiliki tax morale yang lebih rendah. orang yang berpenghasilan tinggi, sudah menikah, lebih tua, dan perempuan memiliki moral pajak yang lebih tinggi. Frey dan Meier(2002) menemukan bahwa sikap pro demokratis, dan nasionalisme berkorelasi positif terhadap moral pajak.

\section{Etika}

Alm dan Torgler (2011) percaya bahwa etika memainkan peranan penting dalam menjelaskan keputusan kepatuhan pajak dan perbedaan etika antar individu yang berbeda. Luthans (2002) menjelaskan keyakinan etis atau tidaknya penghindaran pajak bisa menjadi cara yang efektif untuk memperbaiki kepatuhan pajak terutama bagi pembayar pajak dengan tingkat moral yang lebih rendah. Tingkat kepatuhan pajak akan lebih tinggi jika wajib pajak memiliki moral yang lebih tinggi dengan menganggap penghindaran pajak tidak etis. Sikap etis dipengaruhi oleh kekuatan internal dan eksternal. Faktor internal tidak hanya dipengaruhi oleh faktor individu dan kelompok tetapi juga sejumlah faktor yang relevan seperti budaya, organisasi dan lingkungan eksternal. Sedangkan kekuatan eksternal meliputi politik, hukum, ekonomi, dan perkembangan internasional. Studi dengan pendekatan ekonomi dan hukum seperti tarif pajak dan kompleksitas hukum tidak menghasilkan kesimpulan yang lengkap dikarenanakan hampir 20\% kepatuhan pajak terjadi dijelaskan oleh moral pajak dan etika pajak di negara mereka (McGee, 2012). Penelitian yang dilakukan oleh McGee (2008) menjelaskan penghindaran pajak berdasarkan etika, apakah penghindaran pajak bersifat etis dan dapat diterima dalam beberapa situasi.

\section{METODE PENELITIAN}

\section{Variabel Penelitian}

Dalam penelitian ini, variabel yang digunakan terdiri dari variabel dependen dan variabel independen.Variabel dependen dalam penelitian ini adalah kepatuhan pajak. Selain itu, variabel independennya terdiri dari variabel kebahagiaan, religiusitas, lingkungan, persepsi kelembagaan, dan etika. Variabel kontrolnya adalah variabel ekonomi dan demografi. Variabel ekonomi terdiri atas lama usaha, dan ukuran usaha. Sedangkan variabel demografi terdiri atas jenis kelamin, usia, pendidikan, dan status perkawinan.

\section{Definisi Operasional dan Skala Pengukuran}

1. Kepatuhan pajak adalah suatu keadaan di mana wajib pajak memenuhidan melaksanakan semua kewajiban dan hak perpajakannya (Nurmantu, 2005). Pada penelitian ini, kepatuhan yang diuji ialah kepatuhan pajak secara materiil dimana wajib pajak membayar pajaknya secara konsisten. Variabel ini disimbolkan dengan huruf Y. Variabel dependen penelitian ini yakni dalam bentuk biner yang merupakan modifikasi instrumen penelitian dari Wulansari (2012), di mana 1 untuk UMKM yang membayar pajak secara konsisten dan 0 untuk UMKM yang tidak membayar pajak. Konsisten didefisinikan sebagai kepatuhan formal dan kepatuhan materiil yang dilaksanakan oleh wajib pajak dalam melaporkan semua pendapatan, dan membayar semua pajaknya secara tetap, tidak berubah-ubah, dan sesuai dengan hukum-hukum, aturan-aturan, dan keputusan pengadilan yang berlaku. Apabila UMKM membayar pajak secara konsisten mengindikasikan tingginya kepatuhan dan kesadaran akan pajak. 
2. Kebahagiaan adalah kepuasan responden terhadap keuangan rumah tangga dan hidupnya (Torgler, 2003a). Variabel ini diukur menggunakan data primer yang diolahdari kuesioner (skala likert 7 poin). Hasil modifikasi instrumen dari Torgler (2003a) yang terdiri dari dua pertanyaan. Pada penelitiaan ini, variabel Kebahagiaan diduga berpengaruh positif dan signifikan terhadap kepatuhan pajak.

Tabel 1

Indikator Variabel Kebahagiaan

\begin{tabular}{ll} 
No. & \multicolumn{1}{c}{ Indikator } \\
\hline 1 & Kepuasan finansial (financial satisfaction) \\
2 & Kepuasan hidup
\end{tabular}

3. Religiusitas adalah mekanisme penegakan moral internal guna mencegah sikap negatif dan mendorong sikap positif dalam kehidupan seseorang yang dianggap positif memotivasi pembayar pajak untuk secara sukarela mematuhi peraturan undang-undang perpajakan (Ofiafoh et al., 2016). Variabel ini diukur menggunakan data primer yang diolah dari kuesioner (skala likert 7 poin). Hasil modifikasi instrumen dari Torgler (2003b) yang terdiri dari delapan pertanyaan. Pada penelitian ini,variabel Religiusitas diduga berpengaruh positif dan signifikan terhadap Kepatuhan Pajak.

Tabel 2

Indikator Variabel Religiusitas

\begin{tabular}{cl}
\hline No & \\
\hline 1 & Ketaatan beragama \\
2 & Tingkat Kehadiran dalam Acara Keagamaan \\
3 & Persepsi pentingnya agama \\
4 & Tingkat Kepercayaan pada agama individu \\
5 & Preferensi dan persepsi antara sumbangan keagamaan dengan pajak \\
6 & Persepsi menyisihkan harta untuk orang lain \\
7 & Pengaruh keyakinan religius terhadap tingkah laku \\
8 & Pengaruh keyakinan religius terhadap pendekatan dalam hidup \\
\hline
\end{tabular}

4. Lingkungan adalah faktor yang dapat mempengaruhi keputusan individu dalam melaporkan pajaknya melalui komunikasi kelompok, norma sosial, stigmasi, rasa bersalah dan malu (Alm et al., 1999).Variabel ini diukur menggunakan data primer yang diolah dari kuesioner (skala likert 7 poin). Hasil modifikasi instrument dari Torgler (2003a) dan Susila (2016) yang terdiri dari empat pertanyaan. Pada penelitian ini, variabel Lingkungan diduga berpengaruh positif dan signifikan terhadap Kepatuhan Pajak. 
Tabel 3

Indikator Variabel Lingkungan

\begin{tabular}{cl}
\hline No & \multicolumn{1}{c}{ Indikator } \\
\hline 1 & Pengaruh perilaku dan pandangan individu lain \\
2 & Rasa malu jika tidak membayar pajak \\
3 & Budaya \\
4 & Komunitas atau grup \\
\hline
\end{tabular}

5. Persepsi kelembagaan adalah persepsi seseorang tentang kelembagaan dinegaranya baik otoritas pajak maupun pemerintah. Kelembagaan yang baik dipandang dapat mengekspresikan preferensi, keterlibatan, dan partisipasi individu dalam proses politik sehingga meningkatkan identifikasi lembaga negara dan melawan kecenderungan aktif dalam shadow economy dan penghindaran pajak (Torgler, 2003). Variabel ini diukur menggunakan data primer yang diolah dari kuesioner (skala likert 7 poin). Hasil modifikasi instrumendari Torgler (2003a) dan Susila (2016) yang terdiri dari dua belas pertanyaan. Pada penelitian ini, variabel Persepsi Kelembagaan diduga berpengaruh positif dan signifikan terhadap kepatuhan pajak.

\section{Tabel 4}

Indikator Variabel Persepsi Kelembagaan

\begin{tabular}{cl}
\hline No & \multicolumn{1}{c}{ Indikator } \\
\hline 1 & Nasionalisme \\
2 & $\begin{array}{l}\text { Partisipasi politik dan persepsi tentang pentingnya } \\
\text { pemerintahan }\end{array}$ \\
3 & Pengetahuan dan pemahaman terkait perpajakan \\
4 & Kepercayaan dan persepsi terhadap sistem perpajakan \\
5 & Kepuasan terhadap sistem hokum \\
6 & Kepercayaan terhadap sistem dan aturan hukum. \\
7 & Denda pajak dan pemeriksaan pajak. \\
8 & Probabilitas tertangkap \\
9 & Penyediaan barang publik atau alokasi uang pajak. \\
10 & Kualitas, efektivitas dan efisiensi pemerintahan \\
11 & Transparansi dan akuntabilitas. \\
12 & Sosialisasi pajak/ informasi yang tidaksempurna. \\
\hline
\end{tabular}

6. Etika adalah norma perilaku yang mengatur warga negara sebagai pembayar pajak dalam hubungan mereka dengan pemerintah (Torgler dan Schneider, 2007). Variabel ini diukur menggunakan data primer yang diolah dari kuesioner (skala likert 7 poin). Hasil modifikasi instrument dari McGee (2008) yang terdiri dari 12 pertanyaan. Pada penelitian ini, variabel Etika diduga berpengaruh positif dan signifikan terhadap kepatuhan pajak. 


\section{Tabel 5}

Indikator Variabel Etika

\begin{tabular}{cl}
\hline No & \multicolumn{1}{c}{ Indikator } \\
\hline 1 & Persepsi etika penghindaran pajak terhadap tarif pajak yang terlalu tinggi \\
2 & Persepsi etika penghindaran pajak terhadap tarif pajak yang tidak terlalu tinggi \\
3 & $\begin{array}{l}\text { Persepsi etika penghindaran pajak terhadap proyek-proyek yang tidak } \\
\text { menguntunkan bagi individu }\end{array}$ \\
4 & Persepsi etika penghindaran pajak terhadap proyek-proyek yang bermanfaat \\
5 & Persepsi etika penghindaran pajak terhadap uang pajak yang terbuang sia-sia \\
6 & Persepsi etika penghindaran pajak jika dikorupsi \\
7 & Persepsi etika penghindaran pajak terhadap sistem pajak yang tidak adil \\
8 & Persepsi etika penghindaran pajak terhadap birokrasi yang berbelit \\
9 & Persepsi etika penghindaran pajak jika kemungkinan tertangkap rendah \\
10 & Persepsi etika penghindaran pajak karena tidak akan ketahuan \\
11 & Persepsi etika penghindaran pajak karena tidak mampu membayar \\
12 & Persepsi etika penghindaran pajak karena orang lain juga tidak membayar \\
& pajak
\end{tabular}

7. Jenis kelamin adalah konsep yang memandang bahwa pria dan wanita memiliki respon yang berbeda dalam menghadapi masalah yang sama. Konsep ini tidak hanya sebagai perbedaan biologis akan tetapi memiliki aspek yang lebih luas, seperti sosial, budaya, dan perilaku (Suryajaya, 2015). Variabel ini dalam bentuk biner, di mana 1 untuk laki-laki dan 0 untuk perempuan. Pada penelitian ini, Jenis Kelamin diduga berpengaruh negatif dan signifikan terhadap Kepatuhan Pajak.

8. Usia berpengaruh terhadap kepatuhan wajib pajak. Hal ini dikarenakan wajib pajak yang lebih muda akan lebih berani mengambil resiko, kurang sensitif terhadap hukuman dan reflek sosial, serta perbedaan psikologi dan perbedaan generasi. (Tittle, 1980). Poin yang diberikan untuk jawaban atas pertanyaan ini adalah sesuai dengan jumlah angka usia responden. Pada penelitian ini, usia diduga berpengaruh positif dan signifikan terhadap kepatuhan pajak

9. Pendidikan berhubungan dengan kemampuan wajib pajak untuk memahami dan menaati atau tidak menaati peraturan perpajakan, Jakson dan Miliron (Suryajaya, 2015).poin yang diberikan atas jawaban dari pernyataan ini adalah untuk 1 jenjang SMP, 2 untuk jawaban SMA, 3 untuk jawaban D3, 4 untuk jawaban S1, dan 5 untuk jawaban lainnya (S2 dan S3). Pada peneitian ini, Pendidikan diduga berpengaruh positif dan signifikan terhadap Kepatuhan Pajak.

10.Status perkawinan adalah status atau keadaan responden di mana lengkap tidaknya pasangan hidup yang terikat tali perkawinan. Poin yang diberikan untuk responden sudah menikah yakni 1 dan belum menikah yakni 0. Pada penelitian ini, Status Perkawinan diduga berpengaruh positif dan signifikan terhadap Kepatuhan Pajak.

11.Lama usaha berhubungan dengan semakin lama usaha beroperasi maka semakin berkembang, besar, dan banyaknya pengalaman bisnis yang dimiliki usaha tersebut. Selain itu, semakin besar pula penghasilan yang didapatkan. Sehingga diharapkan usaha tersebut semakin sadar, dan mau untuk membayar pajak (Wulansari (2012). Poin yang diberikan sesuai dengan jumlah angka tahun dari lama usaha berdiri. Pada penelitian ini, Lama Usaha diduga berpengaruh positif dan signifikan terhadap Kepatuhan Pajak. 
12.Ukuran usaha ialah nilai perusahaan UMKM yang dapat diukur dari jumlah karyawan, total nilai asetnya dan nilai penjualan selama satu tahun (Wulansari (2012).

Tabel 6

Penentuan Indeks Ukuran Usaha

\begin{tabular}{llll}
\hline Keterangan & $\begin{array}{l}\text { Jumlah } \\
\text { Karyawan }\end{array}$ & Aset Usaha & Omset Usaha \\
\hline 1. Mikro & <4 Orang & Rp0- Rp50 Juta & Rp0- Rp300 Juta \\
2. Kecil & 5-19 Orang & Rp50 Juta -Rp500 Juta & Rp300 Juta - Rp2,5 Miliar \\
3.Menengah & 20-99 Orang & $\begin{array}{l}\text { Rp500 Juta - Rp10 } \\
\text { Miliar }\end{array}$ & Rp2,5 Miliar - Rp50 Miliar \\
4. Besar & $>100$ Orang & >Rp10 Miliar & $>$ Rp50 Miliar \\
\hline
\end{tabular}

Sumber : Undang-Undang No. 20 Tahun 2008 tentang UMKM

Pengukuran variabel ini merupakan penjumlahan poin atas pertanyaan mengenai jumlah karyawan, aset perusahaan yang dimiliki, dan penjualan perusahaan pertahun yang keduanya menggunakan range ukuran. Berdasarkan hasil penjumlahan tersebut maka hasil penjumlahan dari pertanyaan tersebut akan dikelompokkan sebagai berikut: kelompok usaha mikro untuk nilai antara 1-3, usaha kecil antara 4-6, nilai 7-9 tergolong usaha menengah, dan untuk nilai >9 tergolong usaha besar. Kemudian, UMKM diberi poin penilaian yakni usaha mikro diberi poin 1 , usaha kecil diberi poin 2, usaha menengah diberi poin 3, dan usaha besar diberi poin 4.Pengukuran variabel ini merupakan modifikasi instrumen yang dikembangkan oleh Wulansari (2012).Pada penelitian ini, Ukuran Usaha diduga berpengaruh positif dan signifikan terhadap Kepatuhan Pajak.

\section{Populasi dan Sampel}

Populasi penelitian ini ialah UMKM di Kota Semarang.Rumus Lemeshow digunakan untuk menentukan jumlah sampel karena jumlah populasi yang tidak diketahui atau tidak terhingga.Berikut ini rumus Lameshow:

$n=\frac{z^{2}{ }_{1-\alpha / 2} P(1-P)}{d^{2}}$, Sehingga $n=\frac{1,96^{2}-0,25}{0,1^{2}}=96,04=100$

Berdasarkan rumus tersebut, maka $n$ adalah 96,04 atau dibulatkan menjadi 100 orang sehingga minimal sampel yang harus diambil berjumlah 100 orang. Metode pengambilan sampel dalam penelitian ini adalah purposive random sampling.

\section{Metode Analisis}

Penelitian ini menggunakan model regresi dengan variabel dependen yang bernilai 1 atau 0 , dengan kata lain variabel dependen biner atau dikotomi. Model logit merupakan model yang digunakan untuk menganalisis probabilitas terjadinya suatu peristiwa pada interval $0-1$. Di mana persamaan logit, yakni: 


$$
\mathrm{L}_{Y \mathrm{i}}=\operatorname{Ln}\left(\frac{P i}{1-P i}\right)=\beta_{0}+\beta_{1} \mathrm{X}_{1 \mathrm{i}}+\beta_{2} \mathrm{X}_{2 \mathrm{i}}+\beta_{3} \mathrm{X}_{3 \mathrm{i}}+\beta_{4} \mathrm{X}_{4 \mathrm{i}}+\beta_{5} \mathrm{X}_{5 \mathrm{i}}+\beta_{6} \mathrm{X}_{6 \mathrm{i}}+\mathrm{Z}_{1}+\mathrm{Z}_{2}+\mathrm{Z}_{3}+\mathrm{Z}_{4}+\mathrm{Z}_{5}+\mathrm{Z}_{6 \ldots}
$$

dengan $L_{Y i}:$ Logit $Y ; \operatorname{Ln}\left(\frac{P i}{1-P i}\right)=\operatorname{Ln}\left(\frac{\text { Konsisten Membayar Pajak }}{\text { Tidak Membayar Pajak }}\right)$ : odd ratio dari UMKM patuh terhadap pajak (1 jika UMKM membayar pajak, 0 jika UMKM tidak membayar pajak); $\beta_{0}:$ intercept; $\mathrm{X}_{1}$ :Kebahagiaan; $\mathrm{X}_{2}$ :Religiusitas; $\mathrm{X}_{3}$ : Lingkungan; $\mathrm{X}_{4}$ :Persepsi Kelembagaan; $\mathrm{X}_{5}$ :Etika; $\mathrm{Z}_{1}$ : Jenis Kelamin; $\mathrm{Z}_{2}:$ Usia; $\mathrm{Z}_{3}$ :Pendidikan; $\mathrm{Z}_{4}$ :Status Perkawinan; $\mathrm{Z}_{5}$ :Lama Usaha; $\mathrm{Z}_{6}:$ :Ukuran Usaha; $\mu$ :Errorterm; dan $\beta_{1,2,3,4,5,6,7,8,9,10,11}=$ Slope.

\section{HASIL DAN PEMBAHASAN}

\section{Pengujian LR Fit}

Tabel 7

LR Test

\begin{tabular}{ccc}
\hline \multirow{2}{*}{ Model } & \multicolumn{2}{c}{ Hasil uji } \\
\cline { 2 - 3 } & LR ratio & Sig \\
\hline Model fit & 37,50 & 0,000 \\
\hline
\end{tabular}

Sumber : Data primer 2017, diolah.

Hasil pengujian likelihood rasio mendapatkan nilai LR-rasio sebesar 37,50 dengan signifikansi sebesar 0,000 yang berada di bawah 0,05 . Hal ini mencerminkan bahwa secara bersama-sama variabel independen dalam model tersebut mampu menjelaskan secara statistik signifikan mempengaruhi variabel dependenkepatuhan membayar pajak.

\section{Uji Goodness of fit}

\section{Tabel 8}

Hasil Uji Koefisien Determinasi

\begin{tabular}{cc}
\hline Model & $\boldsymbol{R} 2$ \\
\cline { 2 - 2 } & McFadden \\
\hline Koefisien Determinasi & $\mathbf{0 , 2 3 3 3}$ \\
\hline
\end{tabular}

Sumber : Data primer 2017, diolah. 
Nilai Pseudo R Square diperoleh sebesar 0,23333 menunjukkan bahwa variabel dependen yang dapat dijelaskan oleh variabel independen sebesar 23,33\% dan sisanya sebesar 76,67\% dipengaruhi oleh variabel lain diluar model.

\section{Pengaruh Kondisi Kebahagiaan terhadap Kepatuhan Membayar Pajak}

Hasil pengujian pengaruh kondisi kebahagiaan terhadap kepatuhan membayar pajak diperoleh nilai $\mathrm{Z}$ sebesar 0,67 dengan signifikansi 0,505>0,05. Model tersebut menunjukkan kebahagiaan berpengaruh positif terhadap kepatuhan pajak dan nila signifikansi yang berada di atas 0,05 berarti bahwa kondisi kebahagiaan tidak memiliki pengaruh yang signifikan terhadap kepatuhan membayar pajak.

Nilai odds ratio variabel kebahagiaan $\left(\mathrm{X}_{1}\right)$ sebesar $6 \%$ akan tetapi berdasarkan hasil estimasi diketahui bahwa variabel kebahagiaan berpengaruh tidak signifikan, sehingga variabel kebahagiaan tidak berpeluang untuk mempengaruhi kepatuhan pajak. Pengaruh yang tidak signifikan ini tidak sesuai dengan hasil penelitian (Lubian dan Luca, 2011). Namun, hasil penelitian ini memperkuat hasil temuan (Veenhoven, 2000) yang tidak menemukan hubungan antara ukuran negara sejahtera dengan tingkat kebahagiaan sebuah negara. Hal ini dikarenakan sulitnya untuk menghubungkan tingkat kebahagiaan dari jawaban responden yang normatif terkait preferensi politik, pilihan publik (public choice) dan tingkat kepuasannya terhadap penyediaan pelayanan publik yang disediakan oleh pemerintah.

Penelitian ini menemukan bahwa individu memiliki tingkat kebahagiaan yang beragam.Tingkat kebahagiaan yang tinggi tidak membuat individu merasa memiliki kewajiban untuk patuh terhadap pajak. Akan tetapi, responden dalam hal ini lebih melihat kebahagiaan pada tingkat individu bukan pada tingkat agregrat. Kebahagiaan dipandang bukan untuk memperbaiki sifat dari proses politik, dan tidak menghasilkan efek hedonis.

\section{Pengaruh Religiusitas terhadap Kepatuhan Membayar Pajak}

Hasil pengujian pengaruh religiusitas terhadap kepatuhan membayar pajak diperoleh nilai $\mathrm{Z}$ sebesar 0,55 dengan signifikansi 0,580>0,05. Model tersebut menunjukkan religiusitas berpengaruh positif terhadap kepatuhan pajak dan nilai signifikansi lebih besar dari taraf signifikansi 0,05 berarti religiusitas pemilik usaha tidak berpengaruh signifikan terhadap kepatuhan membayar pajak.

Nilai odds ratio variabel religiusitas $\left(\mathrm{X}_{2}\right)$ sebesar $2 \%$ akan tetapi berdasarkan hasil estimasi diketahui bahwa variabel religiusitas berpengaruh tidak signifikan, sehingga variabel religiusitas tidak berpeluang untuk mempengaruhi kepatuhan pajak. Pengaruh yang tidak signifikan ini tidak sesuai dengan hasil penelitian (Torgler,2003a) dan (Richardson,2008). Namun, hasil penelitian ini memperkuat hasil temuan (Ofiafoh et al.,2006) menjelaskan bahwa nilai-nilai agama saja tidak memainkan peran penting untuk membuat wajib pajak bertanggungjawab atas kepatuhan pajak tapi oleh faktor lain di luar model.

Penelitian ini menemukan bahwa responden dalam hal ini membedakan antara kepatuhan pajak dan ketaatan beragama. Kebanyakan dari responden mengaku dirinya religious, aktif dalam organisasi keagamaan, dibesarkan secara religius, dan percaya terhadap petunjuk keagamaan. Namun, responden tidak memasukan unsur kepatuhan pajak sebagai variabel dari ketaatan beragama. Bahkan, beberapa responden mengatakan bahwa hukum menaati pajak tidak diajarkan, diperintahkan, bahkan diharamkan bagi pemeluk agama tersebut. Sehingga hal inilah yang 
menyebabkan variabel religiusitas tidak mempengaruhi kepatuhan pembayar pajak.

\section{Pengaruh Lingkungan terhadap Kepatuhan Membayar Pajak}

Hasil pengujian pengaruh lingkungan terhadap kepatuhan membayar pajak diperoleh nilai $\mathrm{Z}$ sebesar 2,13 dengan signifikansi $0,033<0,05$. Model tersebut menunjukkan lingkungan berpengaruh positif terhadap kepatuhan pajak. Artinya, individu yang lingkungannya baik memiliki probabilitas lebih besar untuk patuh terhadap pajak dibandingkan individu yang lingkungannya kurang baik. Nilai signifikansi lebih kecil dari taraf signifikansi 0,05 berarti lingkungan berpengaruh signifikan terhadap kepatuhan membayar pajak. Nilai Odd ratio diperoleh sebesar 1,138 yang berarti bahwa persepsi lingkungan yang lebih baik bagi pemilik usaha akan memiliki kepatuhan 1,138 kali lebih besar dibanding dengan yang memiliki kondisi lingkungan usaha yang kurang baik.

Nilai odds ratio peluang variabel lingkungan $\left(\mathrm{X}_{3}\right)$ sebesar $14 \%$ di mana semakin baik lingkungan pemilik usaha maka probabilitas kepatuhan pajak akan naik sebesar $14 \%$. Berdasarkan hasil estimasi, diketahui bahwa variabel lingkungan berpengaruh signifikan, sehingga variabel lingkungan berpeluang untuk mempengaruhi kepatuhan pajak di Kota Semarang.

Penelitian ini menemukan bahwa lingkungan dipengaruhi oleh perilaku dan pandangan yang dilakukan individu lain dalam sebuah kelompok, serta rasa malu jika tidak membayar pajak. Selain itu, nilai-nilai yang sudah tertanam di suatu lingkungan secara lintas generasi juga mempengaruhi kepatuhan pajak individu.Hal ini dikarenakan individu takut kehilangan reputasinya atau mengalami stigma ketika berperilaku tidak jujur.Hasil penelitian ini memperkuat hasil temuan (Bobek et. Al., 2012)

\section{Pengaruh Persepsi Kelembagaan terhadap Kepatuhan Membayar Pajak}

Hasil pengujian pengaruh persepsi kelembagaan terhadap kepatuhan membayar pajak diperoleh nilai $\mathrm{Z}$ sebesar 2,00 dengan signifikansi $0,045<0,05$. Model tersebut menunjukkan persepsi kelembagaan berpengaruh positif terhadap kepatuhan pajak dan nilai signifikansi yang berada di bawah 0,05. Artinya, individu yang memiliki persepsi kelembagaan baik menghasilkan probabilitas lebih besar untuk patuh terhadap pajak dibandingkan individu yang persepsi kelembagaannya tidak baik. Nilai signifikansi lebih kecil dari taraf signifikansi 0,05 berarti persepsi kelembagaan berpengaruh signifikan terhadap kepatuhan membayar pajak. Nilai Odd ratio diperoleh sebesar 1,051 yang berarti bahwa pesepsi mengenai kelembagaan yang lebih baik bagi pemilik usaha akan memiliki kepatuhan 1,051 kali lebih besar dibanding dengan yang memiliki persepsi kelembagaan yang kurang baik.

Nilai odds ratio peluang variabel persepsi kelembagaan $\left(\mathrm{X}_{4}\right)$ sebesar 5\% di mana semakin baik persepsi kelembagaan di sebuah negara maka probabilitas kepatuhan pajak akan naik sebesar5\%. Berdasarkan hasil estimasi,diketahui bahwa variabel persepsi kelembagaan berpengaruh signifikan, sehingga variabel persepsi kelembagaan berpeluang untuk mempengaruhi kepatuhan pajak di Kota Semarang. Hasil penelitian ini menemukan bahwa pembayar pajak merasa korupsi merajalela, penggunaan uang pajak diselewengkan, kepercayaan pada otoritas, pemerintahan sistem hukum, dan sistem perpajakan rendah, sehingga kemauan untuk patuh terhadap pajak rendah. Selain itu, kurangnya sosialisasi, transparansi dan akuntabilitas membuat orang enggan untuk membayar pajak.

Nasionalisme, partisipasi politik dan persepsi pentingnya pemerintahan memainkan peranan 
penting dalam meningkatkan kepatuhan pajak. Hal ini dikarenakan masyarakat merasa bahwa kepentingan (preferensi) benar-benar terwakili oleh institusi politik jika berkontribusi dalam proses politik. Selanjutnya, pengetahuan, pemahaman, kepuasan dan kepercayaan terhadap sistem perpajakan dan hukum dapat meningkatkan moral pajak sehingga pembayar pajak bersedia untuk berkontribusi untuk membayar pajak. Kemudian, penelitian ini jugamenemukan bahwa denda, pemeriksaan, dan penangkapan bagi penghindar pajak menjadi beban bagi wajib pajak sehingga menjadi kepatuhan yang dipaksakan (enforced tax compliance). Selanjutnya, pembayar pajak juga mengharapkan uang pajak yang dibayarkan sesuai dengan penyediaan barang publik.Hasil ini memperkuat hasil temuan (Torgler, 2003a) dan (Frey, 2003) yang menjelaskan pentingnya kelembagaan dalam meningkatkan moral pajak.

\section{Pengaruh Etika terhadap Kepatuhan Membayar Pajak}

Hasil pengujian pengaruh etika terhadap kepatuhan membayar pajak diperoleh nilai Z sebesar 2,37 dengan signifikansi $0,018<0,05$. Model tersebut menunjukkan etika berpengaruh positif terhadap kepatuhan pajak Artinya, individu yang memiliki etika baik menghasilkan probabilitas lebih besar untuk patuh terhadap pajak dibandingkan individu yang etikanya tidak baik. Nilai signifikansi lebih kecil dari taraf signifikansi 0,05 berarti etika berpengaruh signifikan terhadap kepatuhan membayar pajak.Nilai Odd ratio diperoleh sebesar 1,044 yang berarti bahwa pengusaha yang memiliki etika yang lebih baik bagi pemilik usaha akan memiliki kepatuhan 1,044 kali lebih besar dibanding dengan yang memiliki etika yang kurang baik.

Nilai odds ratio peluang variabel etika $\left(\mathrm{X}_{5}\right)$ sebesar $4 \%$ di mana semakin baik etika di sebuah negara maka probabilitas kepatuhan pajak akan naik sebesar 4\%. Berdasarkan hasil estimasi, diketahui bahwa variabel etika berpengaruh signifikan, sehingga variabel etika berpeluang untuk mempengaruhi kepatuhan pajak di Kota Semarang. Hasil penelitian ini memperkuat hasil temuan McGee(2008) dan (Luthans, 2002) yang menjelaskan bahwa etika mempengaruhi moral pajak. Penelitian ini menemukan bahwa pentingnya pertimbangan moral, yakni kemampuan individu untuk menentukan bagaimana mereka akan berperilaku ketika dihadapkan dalam sebuah dilema moral, yang menuntut individu untuk memakai moral yang mereka percayai. Hal ini membuat seseorang mempertimbangkan etika dalam menghindari pajak.

\section{Pengaruh Jenis Kelamin terhadap Kepatuhan Membayar Pajak}

Hasil pengujian pengaruh jenis kelamin terhadap kepatuhan membayar pajak diperoleh nilai $\mathrm{Z}$ sebesar - 0,37 dengan signifikansi 0,710>0,05. Model tersebut menunjukkan jenis kelamin berpengaruh negatif terhadap kepatuhan pajak dan nilai signifikansi lebih besar dari taraf signifikansi o,05 berarti jenis kelamin tidak memiliki pengaruh yang signifikan terhadap kepatuhan membayar pajak.

Nilai odds ratio variabel jenis kelamin $\left(\mathrm{X}_{6}\right)$ sebesar $-16 \%$ dan berdasarkan hasil estimasi diketahui bahwa variabel jenis kelamin berpengaruh tidak signifikan, sehingga variabel jenis kelamin tidak berpeluang untuk mempengaruhi kepatuhan pajak. Hasil penelitian ini memperkuat hasil temuan Widianto (2015) yang menunjukkan bahwa jenis kelamin dari pembayar pajak secara statistik tidak signifikan dalam mempengaruhi kepatuhan pajak individu. Sehingga dapat diartikan tidak ada perbedaan pertimbangan yang digunakan oleh pria dan wanita dalam perilaku kepatuhan pajak. Pria dan wanita memiliki keputusan yang sama untuk berperilaku patuh atau tidak patuh terhadap hukum pajak yangberlaku. 


\section{Pengaruh Usia terhadap Kepatuhan Membayar Pajak}

Hasil pengujian pengaruh usia terhadap kepatuhan membayar pajak diperoleh nilai Z sebesar 1,00 dengan signifikansi 0,317>0,05. Model tersebut menunjukkan usia berpengaruh negative terhadap kepatuhan pajak dan nilai signifikansi lebih besar dari taraf signifikansi 0,05 berarti usia tidak berpengaruh signifikan terhadap kepatuhan membayar pajak.

Nilai odds ratio variabel usia $\left(\mathrm{X}_{7}\right)$ sebesar $-3 \%$ dan berdasarkan hasil estimasi diketahui bahwa variabel usia berpengaruh tidak signifikan, sehingga variabel usia tidak berpeluang untuk mempengaruhi kepatuhan pajak. Hasil penelitian ini memperkuat hasil temuan Widianto (2015) yang menunjukkan bahwa jenis kelamin dari pembayar pajak secara statistik tidak signifikan dalam mempengaruhi kepatuhan pajak individu. Sehingga dapat diartikan tidak terdapat perbedaan antara generasi, setiap kelompok usia, baik yang muda dan yang lebih tua memiliki kecenderungan untuk patuh terhadap hukum pajak yang berlaku

\section{Pengaruh Pendidikan terhadap Kepatuhan Membayar Pajak}

Hasil pengujian pengaruh pendidikan terhadap kepatuhan membayar pajak diperoleh nilai $\mathrm{Z}$ sebesar 0,71 dengan signifikansi 0,480>0,05. Model tersebut menunjukkan pendidikan berpengaruh positif terhadap kepatuhan pajak dan nilai signifikansi lebih besar dari taraf signifikansi 0,05 berarti pendidikan tidak berpengaruh signifikan terhadap kepatuhan membayar pajak. Nilai odds ratio variabel pendidikan $\left(\mathrm{X}_{8}\right)$ sebesar $19 \%$ akan tetapi berdasarkan hasil estimasi diketahui bahwa variabel pendidikan berpengaruh tidak signifikan, sehingga variabel pendidikan tidak berpeluang untuk mempengaruhi kepatuhan pajak. Hasil penelitian ini memperkuat hasil temuan Torgler (2003a) yang menjelaskan bahwa orang yang berpendidikan semakin tinggi memiliki tax morale yang lebih rendah. Lewis (Torgler, 2003a) juga menjelaskan bahwa pendidikan berhubungan dengan pengetahuan wajib pajak tentang hukum pajak seperti UU pajak dan hubungan fiskal.Wajib pajak yang memiliki tingkat pendidikan lebih tinggi seharusnya lebih menyadari manfaat dan layanan yang diberikan negara kepada masyarakat dari pajak, sehingga seharusnya memiliki moral pajak yang lebih tinggi. Namun,disisi lain,mereka mungkin akan memiliki kepatuhan pajak yang lebih rendah karena lebih memahami peluang menghindari pajak dan mungkin akan lebih kritis dan sadar bagaimana seharusnya negara menggunakan pajak.

\section{Pengaruh Status Perkawinan terhadap Kepatuhan Membayar Pajak}

Hasil pengujian pengaruh status perkawinan terhadap kepatuhan membayar pajak diperoleh nilai $\mathrm{Z}$ sebesar 0,24 dengan signifikansi $0,807>0,05$. Model tersebut menunjukkan status perkawinan berpengaruh positif terhadap kepatuhan pajak dan nilai signifikansi lebih besar dari taraf signifikansi 0,05 berartistatus perkawinan tidak berpengaruh signifikan terhadap kepatuhan membayarpajak.

\section{Pengaruh Lama Usaha terhadap Kepatuhan MembayarPajak}

Hasil pengujian pengaruh lama usaha terhadap kepatuhan membayar pajak diperoleh nilai $\mathrm{Z}$ sebesar 2,20 dengan signifikansi $0,028<0,05$. Model tersebut menunjukkan lama usaha berpengaruh positif terhadap kepatuhan pajak. Artinya, semakin lama usaha beroperasi memiliki probabilitas 
lebih besar untuk patuh terhadap pajak dibandingkan usaha yang baru merintis atau belum lama beroperasi. Nilai signifikansi lebih kecil dari taraf signifikansi 0,05 berartilama usaha memiliki pengaruh yang signifikan terhadap kepatuhan membayar pajak. Nilai Odd ratio diperoleh sebesar 1,13 yang berarti bahwa lama usaha yang lebih lama akan memiliki kepatuhan 1,13 kali lebih besar dibanding dengan yang memiliki lama usaha yang lebih kecil.

Nilai odds ratio peluang variabel lama usaha $\left(\mathrm{X}_{10}\right)$ sebesar $13 \%$ di mana semakin lama usaha berdiri maka probabilitas kepatuhan pajak akan naik sebesar 13\%. Berdasarkan hasil estimasi,diketahui bahwa variabel lama usaha berpengaruh signifikan, sehingga variabel lama usaha berpeluang untuk mempengaruhi kepatuhan pajak di Kota Semarang. Hasil penelitian ini memperkuat hasil temuan Wulansari (2012) bahwa faktor lama berdirinya usaha berpengaruh positif signifikan terhadap pengetahuan dan pemahaman pajak.Pemahaman pajak memiliki hubungan signifikan terhadap kepatuhan wajib pajak. Berdasarkan pernyataan tersebut, dapat disimpulkan bahwa semakin lama usaha beroperasi maka semakin berkembang, besar, banyaknya pengalaman bisnis yang dimiliki usaha tersebut, dan semakin banyaknya penghasilan yang didapatkan sehingga meningkatkan kepatuhan pajak UMKM dalam membayar dan patuh terhadap pajak. Selain itu, usaha yang lebih lama beroperasi akan cenderung lebih stabil, dan memiliki pembukuan yang baik . Apabila usaha berorientasi jangka panjang akan lama mencapai titik Break Even Point (BEP) sehingga membutuhkan waktu cukup lama untuk UMKM tersebut mampu membayar pajaknya setelah modal usaha kembali dan mengalami keuntungan. Selain itu, persepsi responden tentang pentingnya pelaporan keuangan merupakan suatu hal yang penting bagi pertumbuhan dan perkembangan usaha karena meningkatkan kesadaran dalam melaporkan pajaknya. Penelitian ini menemukan bahwa lama usaha belum menjadi fokus pemerintah dalam penetapan tarif pajak, usaha yang baru berdiri harus tetap membayar pajak UMKM sebesar 1\% dari omset.

\section{Pengaruh Ukuran Usaha terhadap Kepatuhan Membayar Pajak}

Hasil pengujian pengaruh ukuran usaha terhadap kepatuhan membayar pajak diperoleh nilai $\mathrm{Z}$ sebesar 2,61dengan signifikansi 0,009<0,05. Model tersebut menunjukkan ukuran usaha berpengaruh positif terhadap kepatuhan pajak.Artinya, semakin besar ukuran usaha memiliki probabilitas lebih besar untuk patuh terhadap pajak dibandingkan ukuran usaha yang lebih kecil. Nilai signifikansi yang berada di bawah 0,05 menunjukkan bahwa ukuran usaha berpengaruh signifikan terhadap kepatuhan membayar pajak. Nilai Odd ratio diperoleh sebesar 3,28 berarti bahwa ukuran usaha yang lebih besar akan memiliki kepatuhan 3,28 kali lebih besar dibanding dengan ukuran usaha yang lebih kecil.

Nilai odds ratio peluang variabel ukuran usaha $\left(\mathrm{X}_{11}\right)$ sebesar $28 \%$, sehingga semakin besar ukuran usaha maka probabilitas kepatuhan pajak akan naik sebesar $28 \%$. Berdasarkan hasil estimasi, diketahui bahwa variabel ukuran usaha berpengaruh signifikan, sehingga variabel ukuran usaha berpeluang untuk mempengaruhi kepatuhan pajak di Kota Semarang. Wulansari (2012) menjelaskan bahwa ukuran usaha berpengaruh positif terhadap kepatuhan pajak.

Hasil penelitian ini menemukan bahwa beberapa UMKM tidak setuju dengan penetapan tarif pajak $1 \%$ berdasarkan omset yang tidak melebihi Rp4,8 miliar dalam satu tahun pajak.Hal ini dikarenakan kondisi, dan tipe usaha yang berbeda-beda sehingga rentang tarif pajak dirasa terlalu besar, flat, dan memberatkan. Selain itu, margin keuntungan dan sensitivitas harga tiap usaha berbeda-beda.Hal ini membuat UMKM memiliki preferensi untuk melaporkan pajaknya dengan tidak jujur dibandingkan harus membayar pajak yang terlalu besar. Beberapa responden menyatakan bahwa seharusnya penetapan besaran tariff pajak berdasarkan asas keadilan yakni dilihat dari laba 
bersih bukan omset sehingga dapat menyesuaikan usaha saat lesu dan defisit. Selain itu, UMKM mau membayar pajak apabila realisasinya dirasakan sesuai dengan pajak yang dibayarkan seperti peningkatan pelayanan publik. Selain itu, usaha dengan barrier entry yang rendah, memiliki banyak pesaing usaha sejenis, dan sangat sensitif terhadap harga akan membuat UMKM tersebut kesulitan untuk patuh terhadappajak.

\section{KESIMPULAN}

Hasil penelitian menunjukkan bahwa faktor-faktor yang secara signifikan mempengaruhi kepatuhan pajak adalah lingkungan, persepsi kelembagaan, etika, lama usaha, dan ukuran usaha. Variabel yang tidak signifikan berpengaruh terhadap kepatuhan pajak yakni kebahagiaan, religiusitas, jenis kelamin, usia, pendidikan, dan status perkawinan sehingga variabel-variabel tersebut tidak berpeluang untuk mempengaruhi kepatuhan pajak UMKM di Kota Semarang.

Berdasarkan hasil penelitian ditemukan bahwa UMKM memiliki permasalahan terkait persepsi kelembagaan yang kurang baik terhadap pemerintahan, sistem hukum, dan system perpajakan di Indonesia pada umumnya dan Semarang pada khususnya. Hal ini berdampak pada kepercayaan dan kemauan UMKM dalam membayar pajak. Besaran tarif, tingkat korupsi, kurangnya sosialisasi, keadilan, transparansi dan pengalokasian uang pajak menjadi faktor utama yang mempengaruhi kepatuhan pajak dan tingkat tax morale UMKM dari perspektif kelembagaan. Sedangkan, dari perspektif lingkungan, UMKM cenderung takut kehilangan reputasi dan stigmasi jika menghindari pajak. Selain itu, norma sosial yang ada di masyarakat juga berpengaruh terhadap keputusan individu untuk patuh terhadap pajak. Kemudian, keyakinan etis atau tidaknya penghindaran pajak bisa menjadi cara yang efektif untuk memperbaiki kepatuhan pajak terutama bagi pembayar pajak dengan tingkat moral yang lebih rendah. Dalam hal ini, penghindaran pajak bisa bersifat etis dibeberapa kasus seperti tingginya tingkat korupsi, pajak yang disia-siakan oleh pemerintah, sistem pajak yang tidak adil, dan birokrasi yang berbelit.

Berdasarkan permasalahan dan kesimpulan, peneliti mengemukakan beberapa saran sebagai berikut. Pertama, Pemerintah harus mampu menjadi kontrol sosial dengan mencegah penghindaran pajak membudaya di lingkungan masyarakat. Hal ini dapat dilakukan dengan memberikan stigmatisasi buruk dan sanksi sosial jika menghindari pajak sehingga ada perasaan bersalah dan malu jika tidak patuh terhadap pajak dengan mempertimbangkan norma sosial yang tertanam di masyarakat. Kedua, perbaikan kelembagaan harus menjadi perhatian pemerintah dengan memperbaiki kepercayaan masyarakat terhadap sistem hukum, pemerintahan, dan perpajakan sehingga persepsi yang tertanam di masyarakat menjadi lebih baik. Selain itu, keterlibatan wajib pajak juga harus ditingkatkan dengan memberikan ruang publik untuk menyuarakan aspirasi mereka terkait kebijakan yang dibuat pemerintah dan pelayanan publik yang diberikan. Ketiga, pemerintah harus melihat perbedaan etika antar individu atau kelompok yang berbeda terkait keyakinan etis atau tidaknya penghindaran pajak. Selain itu, pemerintah harus mempertimbangkan dan menganalisa kondisi sosial, politik, budaya, hukum, dan ekonomi yang terjadi dikaitkan dengan tingkat kepatuhan pajak dan karakteristik di wilayah setempat. Keempat, pemerintah sebaiknya mengkategorikan rentang tarif pajak yang lebih spesifik berdasarkan sektor usaha, dan ukuran usaha

(mikro, kecil, menengah, dan besar) dengan mengaitkan margin keuntungan yang rata-rata diperoleh sektor usaha tersebut.Selain itu, kondisi, tipe, dan lama usaha juga harus dipertimbangkan dalam hal ini. 


\section{DAFTAR PUSTAKA}

1) Allingham, M.G., \& A. Sandmo. 1972. "Income Tax Evasion: A Theoretical Analysis". Journal of Public Economics", h.323-338.

2) Alm, J., McClelland, G.H., dan Schulze, W.D. 1999. "Changing the Social Nrm of Tax Compliance by Voting". Kyklos, 52(2), h.141-171.

3) Alm, J., dan B. Torgler. 2011. "Do Ethics Matter? Tax Compliance and Morality". Journal of Business Ethics. Vol. 101, Issue 4, h.635-651.

4) Bobek et. al. 2012. "Analyzing the Role of Social Norms in Tax Compliance Behavior”. New York: Springer. Journal of Business Ethics. Vol.115, h.451-468.

5) Bohnet, I., dan B. S. Frey. 1994. "Direct Democratic Rules: The Role of Discussion". Kylos. Vol.47, h.341-354.

6) Cialdini, Robert B, dan M.R Torst. 1998. Social Influence: Social Norms, Conformity and Compliance.

7) DJP Kanwil Jawa Tengah I. 2017. Penerimaan Pajak di Direktorat Jenderal Pajak Kantor Wilayah Jawa Tengah I. CD ROM. Semarang.

8) Fret, B.S. dan S. Meier 2002. "Pro Social Behavior, Reciprocity or Both? Journal ofEconomic Behavior and Organization. Working Paper No. 107, University of Zurich.

9) Frey, B. S. 2003. "The Role of Deterrence and Tax Morale in Taxation in the European Union". Journal of Humanities and Social Sciences.

10) Frey, Bruno S., dan Alois Stutzer. 2010. Happiness and Public Choice. New York: Springer Science. Vol.144, h.557-573.

11) James, S., J. Hasseldine., P Hite, dan M Toumi. 2001. "Developing a Tax Compliance Strategy for Revenue Services”. Bulettin for International Fiscal Documentation. Vol.55, h.158-164.

12) Kementerian Keuangan. 2017. Media Keuangan: Semangat Perbaikan. Volume XII, No.114.

13) Lubian, Diego, dan Luca Zarri. 2011. "Happiness and Tax Morale: An Empirical Analysis." Italy: Elsevier. Journal of Economic Behavior and Organization. Vol. 80, h.223-243.

14) Luthans, Fred. 2002. Organizational Behavior. MCGraw Hill Companies, Inc, New York.

15) Luttmer, Erzo. F.P., dan M. Singhal. 2014. “Tax Morale”. Journal of Economic Perspectives. Vol. 28, No.4, h.149-168.

16) McGee, dan Robert W. 2008. Taxation and Public Finance in Transition and Developing Economies. New York: Springer.

17) McGee, dan Robert W. 2012. The Ethics of Tax Evasion: Perspectives in Theory and Practice. New York: Springer.

18) Musgrave, R. A. 1959. The Theory of Public Finance: A Study in Political Economy. New York: McGraw-Hill.

19) Nurmantu, S. 2005. Pengantar Perpajakan. Jakarta: Granit.

20) Ofiafoh, et.al. 2016. "Religiosity and Tax Compliance: Empirical Evidence From Nigeria". Journal of Accounting. Vol. 1 February 2016. 
21) Richardson, G. 2008. "The Relationship Between Culture and Tax Evasion Across Countries: Additional Evidence and Extensions". Journal of International Accounting, Auditing, and Taxation. Vol. 17. H.67-78.

22) Seputar Indonesia (Sindo). (2016). "Jumlah UMKM di Semarang Meningkat 1,97\% TiapTahun”.https://ekbis.sindonews.com, diakses 01 Desember 2017.

23) Smith, A. (2015). The Theory of Moral Sentiments.

24) Suryajaya, P. 2015. "Pengaruh Norma Sosial dan Faktor-Faktor Demografi Terhadap Kepatuhan Pajak (Studi kasus pada Para Pendeta di Semarang)". Skripsi. Universitas Diponegoro.

25) Susila, B. 2016. "Wajib Pajak dan Generasi Muda: Tax Morale Mahasiswa di Indonesia". Journal Economics and Business. Universitas Indonesia.

26) Tittle, C. 1980. Sanctions and Social Deviance: The Question of Detterence. New York: Praeger.

27) Torgler, B., dan Cristoph A.S. 2005. "Tax Morale and Fiscal Policy”. Journal Management and the Arts (CREMA).Working Paper. No.2005-30.

28) Torgler, B, dan F.Schneider. 2007. The Impact of Tax Morale and Institutional Quality on the Shadow Economy. Germany: The Institute for the Study of Labor (IZA). Discussion Paper (DP). No. 2541.

29) Torgler, B. 2003a. "Tax Morale: Theory and Empirical Analysis of Tax Compliance". Disertasi. Universitas Basel.

30) Torgler, B. 2003b. "The Importance of Faith: Tax Morale and Religiosity". Journal of Economics, Management and the Arts (CREMA). Working Paper No. 2003-08.

31) Veenhoven, R., 2000. "Wellbeing in the Welfare State". Journal of Comparative Policy. h.91125.

32) Widianto, R.2015. The Effect of Demographic Factors on Individual Tax Compliance in Duren Sawit (East Jakarta, Indonesia).Disertasi. International Institute of Social Studies.

33) Wulansari, A. 2012. "Analisis Tingkat Kesadaran Pajak pada Usaha Mikro, Kecil, dan Menegah (UMKM). Skripsi. Universitas Indonesia. 